\title{
Analisis Spasial Kasus Diare pada Balita di Kabupaten Banyumas Tahun 2019
}

\author{
Dyah Nurmarastri Sasabil Sidqi", Novia Anasta, Pralampita Kori Mufidah \\ Departemen Biostatistika dan Ilmu Kependudukan Fakultas Kesehatan Masyarakat \\ Universitas Indonesia
}

*Korespondensi: Dyah Nurmarastri Sasabil Sidqi - dyahnursmarastriss@ gmail.com

\begin{abstract}
Abstrak
Diare merupakan penyebab kematian balita terbesar kedua di seluruh dunia. Indonesia sendiri prevalensi diare untuk balita merupakan tertinggi dari seluruh kelompok umur sebesar 11,5\% pada tahun 2018. Hingga tahun 2019 angka penemuan diare pada balita di Kabupaten Banyumas masih belum mencapai target yang ditentukan. Belum adanya gambaran spasial daerah yang rentan akan peningkatan kasus diare balita mempersulit upaya penemuan kasus yang penting dilakukan untuk mencegah terjadinya KLB. Tujuan penelitian ini yaitu mendeskripsikan, dan melakukan analisis spasial untuk melihat korelasi faktor risiko dengan kasus diare pada balita secara geografis melalui peta kerentanan serta menghasilkan peta buffer jangkauan pelayanan puskesmas di Kabupaten Banyumas Tahun 2019. Penelitian ini menggunakan studi ekologi dengan pendekatan spasial untuk mengetahui korelasi faktor risiko dengan kasus diare pada balita secara geografis. Analisis spasial menunjukan terdapat 10 kecamatan yang teridentifikasi memiliki kerentanan tinggi terhadap kejadian diare pada balita di Kabupaten Banyumas. Hasil analisis buffer puskesmas terhadap wilayah kerjanya menunjukkan terdapat kecenderungan wilayah kerentanan tinggi merupakan wilayah yang termasuk dalam jangkauan maksimal pelayanan puskesmas sejauh $5 \mathrm{~km}$. Perlu ditingkatkan kewaspadaan pada wilayah kerentanan tinggi kasus diare pada balita di Kabupaten Banyumas.
\end{abstract}

Keyword: analisis spasial, diare balita, wilayah rentan

\section{Spatial Analysis of Diarrhea Cases in Children Under Five in Banyumas District in 2019}

\begin{abstract}
Diarrhea is the second leading cause of child mortality worldwide. In Indonesia, the prevalence of diarrhea in children under five is the highest of all age groups at 11.5\% in 2018. Until 2019, the number of diarrhea findings in children under five in Banyumas District has not yet reached the target. The absence of a spatial description of areas that are vulnerable to an increase in cases of diarrhea under five makes it difficult to detect cases that are important to prevent outbreaks. This study aims to describe and conduct spatial analysis to see the correlation of risk factors with cases of diarrhea in children under five geographically through a vulnerability map and to produce a buffer map for the coverage of puskesmas in Banyumas District in 2019. This study uses an ecological study with a spatial approach to determine the correlation of factors risk with cases of diarrhea in children under five geographically. Spatial analysis shows that there are 10 sub-districts identified as having high susceptibility to diarrhea in children under five in Banyumas District. The results of the buffer analysis of the puskesmas towards their working areas indicate that there is a tendency for high vulnerability areas to be included in the maximum reach of puskesmas services as far as $5 \mathrm{~km}$. It is necessary to increase vigilance in areas of high susceptibility to diarrhea cases in children under five in Banyumas District.
\end{abstract}

Keywords: spatial analysis, diarrhea in children under five, vulnerable areas 


\section{PENDAHULUAN}

Diare adalah penyakit menular yang ditandai dengan adanya buang air besar dalam bentuk cair sebanyak 3 kali sehari atau lebih dari normal, terkadang dapat disertai oleh darah. Diare dapat terjadi pada rentang usia berapapun dari mulai anak-anak hingga lansia. Diare juga sering terjadi pada anak-anak khususnya anak berusia dibawah lima tahun (BALITA) (1).

Diare merupakan penyebab kematian balita terbesar kedua di dunia dengan angka kematian sebanyak 526.000 balita di tahun 2015. Sebanyak 5\% dari jumlah kematian balita akibat diare terjadi di kawasan Asia Tenggara. Di Indonesia angka kematian balita akibat diare pada tahun 2015 sebanyak 8.600 balita menempati peringkat 12 dari 15 negara dengan angka kematian balita tertinggi di dunia dan tertinggi di Asia Tenggara (1).

Saat ini angka kematian yang disebabkan diare di tingkat dunia sebesar 3,8 per 1.000 kasus per tahun, median insidens secara keseluruhan pada anak usia dibawah 5 tahun adalah 3,2 anak per tahun. Diare masih menjadi penyebab kematian utama balita di Indonesia sebesar 25,2\% (2). Menurut data Riskesdas 2018, menurut diagnosis tenaga Kesehatan prevalensi diare sebesar $6,8 \%$ dan gejala yang pernah dialami sebesar 8\%. Kelompok umur dengan prevalensi diare (berdasarkan diagnosis tenaga Kesehatan) tertinggi yaitu pada kelompok umur 1-4 tahun sebesar 11,5\% dan pada bayi sebesar 9\% (3).

Berdasarkan Profil Kesehatan Tahun 2019, Kabupaten Banyumas memiliki jumlah penduduk sebesar 1.840.152 dengan jumlah target penemuan diare pada balita sebesar 18.478 dan kasus diare dilayani pada Balita sebesar 10.617 atau 57,5\%. Angka penemuan kasus ini masih belum mencapai target yang diharapkan yaitu $80 \%$ (4).

Faktor risiko diare dibagi menjadi 3 yaitu faktor karakteristik individu, faktor perilaku pencegahan, dan faktor lingkungan. Faktor karakteristik individu yaitu umur balita <24 bulan, status gizi balita, dan tingkat pendidikan pengasuh balita. Faktor perilaku pencegahan diantaranya, yaitu perilaku mencuci tangan sebelum makan, mencuci peralatan makan sebelum digunakan, mencuci bahan makanan, mencuci tangan dengan sabun setelah buang air besar, dan merebus air minum, serta kebiasaan memberi makan anak di luar rumah. Faktor lingkungan meliputi kepadatan penduduk, kepadatan perumahan, ketersediaan sarana air bersih (SAB), pemanfaatan SAB, dan kualitas air bersih (5).

Faktor lingkungan merupakan faktor yang paling dominan atas kejadian diare, diantaranya yaitu sarana penyediaan air bersih dan pembuangan tinja. Kedua faktor 
berinteraksi bersama dengan perilaku manusia. Apabila faktor lingkungan tidak sehat karena tercemar kuman diare serta terakumulasi dengan perilaku manusia yang tidak sehat, maka penularan diare dengan mudah dapat terjadi (6).

Oleh karenanya diperlukan penggunaan Sistem Informasi Geografis untuk memetakan distribusi dan menganalisis secara spasial risiko penyakit diare pada balita berdasarkan variabel faktor risiko, terutama pada wilayah Kabupaten Banyumas. Sehingga peta ini dapat digunakan oleh pemerintah Kabupaten Banyumas sebagai bahan pertimbangan pengambilan keputusan khususnya terkait pencegahan dan penanggulangan kasus diare balita.

Tujuan penelitian ini yaitu mendeskripsikan dan melakukan analisis spasial untuk melihat korelasi faktor resiko dengan kasus diare pada balita secara geografis melalui peta kerentanan serta menghasilkan peta buffer jangkauan pelayanan puskesmas di Kabupaten Banyumas Tahun 2019.

\section{METODE}

Metode yang digunakan dalam penelitian ini adalah studi ekologi dengan pendekatan spasial untuk melihat korelasi variabel independen dengan kejadian diare balita secara geografis. Menurut Coogon,
Rose dan Barker (2003) studi ekologi menggunakan populasi atau kelompok sebagai unit analisisnya (7).

Variabel dependen yang digunakan dalam penelitian ini yaitu kasus diare pada balita di Kabupaten Banyumas, sedangkan variabel independen yaitu faktor risiko diare yang akan diuji yaitu kepadatan penduduk, status gizi buruk, sumber air minum, cakupan KK akses jamban sehat dan desa stop Buang Air Besar (BAB) sembarangan.

Data yang digunakan dalam penelitian ini yaitu data primer dan data sekunder. Data primer didapatkan dengan penitikan koordinat puskesmas pada fitur Google maps dan data sekunder berupa data variabel dependen dan independen didapatkan dari profil kesehatan Kabupaten Banyumas serta profil Kabupaten Banyumas tahun 2019.

Penelitian ini menggunakan analisis spasial metode skoring dengan memberikan skor terhadap klasifikasi tinggi, sedang dan rendah. Kemudian dilakukan overlay atau analisis tumpang susun untuk mendapatkan peta distribusi risiko dan peta kerentanan diare pada balita. Selain itu dilakukan juga analisis buffer terhadap puskesmas di Kabupaten Banyumas untuk mendapatkan peta jangkauan pelayanan puskesmas. Analisis data dilakukan menggunakan menggunakan fitur spatial analysis software ArcGIS 10.4. 
Tabel 1. Klasifikasi Skor

\begin{tabular}{ccc}
\hline Klasifikasi & Kelas & Skor \\
\hline Tinggi & 1 & 15 \\
Sedang & 2 & 10 \\
Rendah & 3 & 5 \\
\hline
\end{tabular}

Metode skoring atau metode pembobotan adalah teknik untuk mengambil keputusan yang melibatkan beberapa faktor secara bersamaan dengan pemberian bobot/skor pada masing-masing faktor. Dalam analisis pembobotan/skoring, pemberian bobot/skor sifatnya subjektif sehingga pengguna perlu memahami sifat faktor yang akan diberikan skor/bobot (8).

Analisis buffer adalah analisis yang menghasilkan informasi mengenai jarak jangkauan dari suatu objek sehingga diperoleh suatu area/buffer di sekitar objek. Salah satu kegunaan analisis buffer memudahkan penggunanya untuk mengetahui kondisi aksesibilitas suatu sarana dan prasarana (9).

Analisis buffer dilakukan pada puskesmas dengan standar radius pencapaian ke puskesmas yang ideal menurut Badan Standardisasi Nasional (2004) sejauh 3 km (10). Hal ini berkaitan dengan persepsi keterjangkauan masyarakat terhadap fasilitas pelayanan kesehatan. Selain itu dilakukan pula analisis buffer sejauh $5 \mathrm{~km}$ sebagai asumsi jarak maksimal jangkauan masyarakat ke pelayanan kesehatan untuk melihat wilayah kerja puskesmas yang berisiko keterlambatan mengakses ke puskesmas (11).

\section{HASIL}

\section{Distribusi risiko kasus diare pada balita terhadap kepadatan penduduk}

Peta distribusi risiko diare balita terhadap kepadatan penduduk (Gambar 1) menunjukkan sebagian besar wilayah kecamatan di kabupaten banyumas memiliki risiko sedang (13 kecamatan) dan risiko rendah (12 kecamatan). Sedangkan hanya 2 kecamatan berisiko tinggi terhadap kepadatan penduduk yaitu kecamatan Purwokerto Selatan dan Purwokerto Barat.

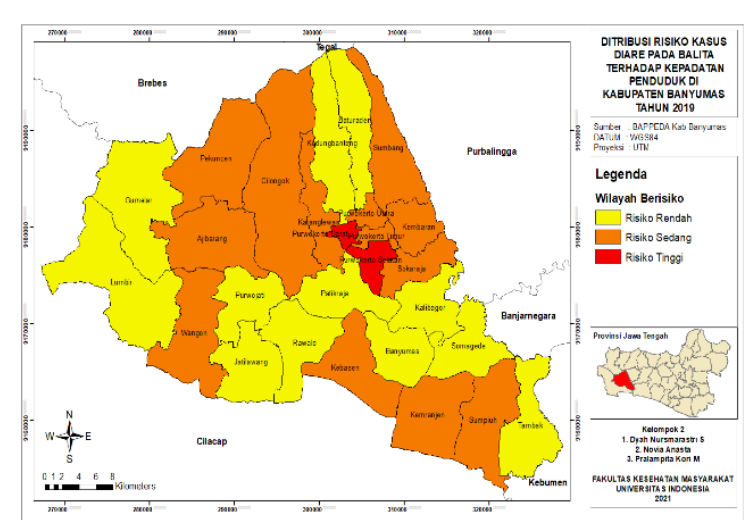

Gambar 1. Distribusi Risiko Kasus Diare pada Balita Terhadap Kepadatan Penduduk di Kab. Banyumas Tahun 2019

\section{Distribusi risiko kasus diare pada balita terhadap sarana air minum memenuhi syarat}

Peta distribusi risiko diare balita terhadap sarana air minum memenuhi syarat (Gambar 2) menunjukkan sebagian besar wilayah kecamatan di kabupaten banyumas memiliki risiko sedang (16 kecamatan), diikuti risiko tinggi (6 kecamatan) dan risiko rendah (5 kecamatan). Kecamatan berisiko tinggi 
yaitu Pekuncen, Cilongok, Purwokerto

Barat, Kebasen, Kemranjen dan Sumpiuh.

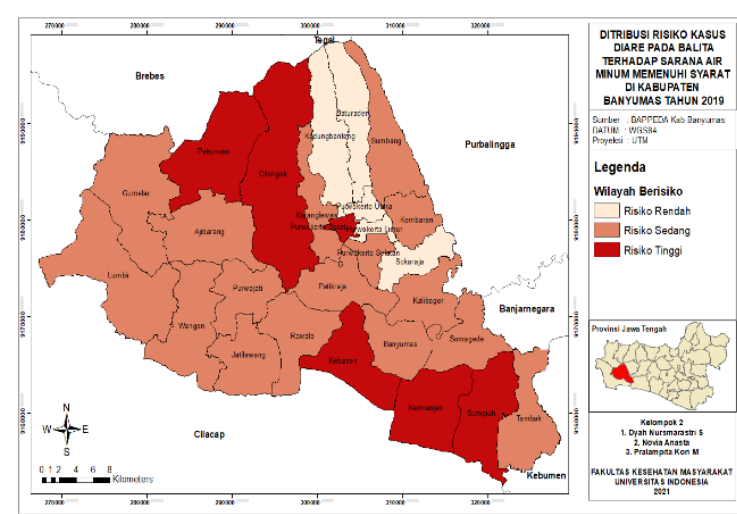

Gambar 2. Distribusi Risiko Kasus Diare pada Balita Terhadap Sarana Air minum Memenuhi Syarat di Kab. Banyumas Tahun 2019

\section{Distribusi risiko kasus diare pada balita} terhadap status gizi buruk

Peta distribusi risiko diare balita terhadap status gizi buruk balita (Gambar 3) menunjukkan sebagian besar wilayah kecamatan di kabupaten banyumas memiliki risiko rendah (13 kecamatan), diikuti risiko sedang (7 kecamatan) dan risiko tinggi (7 kecamatan). Kecamatan yang berisiko tinggi antara lain Ajibarang, Cilongok, Sumbang, Kembaran, Sokaraja, Kemranjen dan Kebasen.

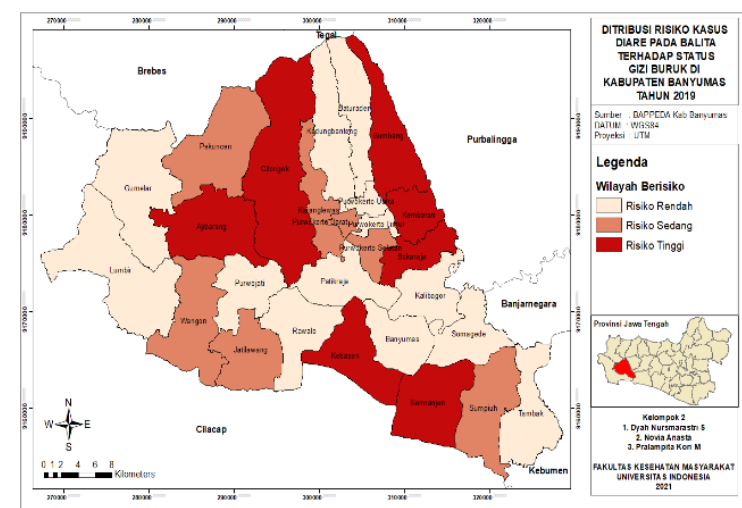

Gambar 3. Distribusi Risiko Kasus Diare pada Balita Terhadap Status Gizi Buruk di Kab. Banyumas Tahun 2019

\section{Distribusi risiko kasus diare pada balita terhadap cakupan KK akses jamban sehat}

Faktor risiko cakupan KK terhadap akses jamban sehat yang di analisis spasial menggunakan metode skoring hingga dihasilkan peta distribusi risiko kasus diare pada balita terhadap cakupan akses KK ke jamban sehat (Gambar 4) menunjukkan sebagian besar kecamatan di Kabupaten Banyumas memiliki tingkat risiko rendah (12 kecamatan), risiko sedang (8 kecamatan), serta risiko tinggi (7 kecamatan). Kecamatan berisiko tinggi Pekuncen, Cilongok, Ajibarang, Karanglewas, Sumbang, Kembaran, Kemrajen

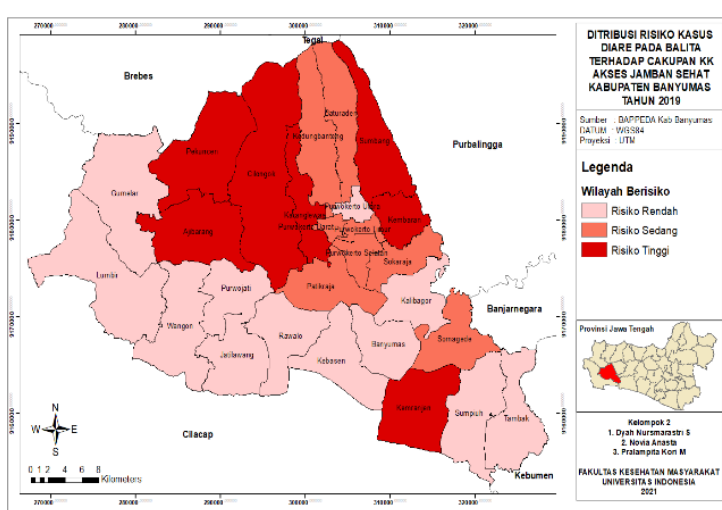

Gambar 4. Distribusi Risiko Kasus Diare pada Balita Terhadap Cakupan Akses KK ke Jamban Sehat di Kab. Banyumas Tahun 2019

\section{Distribusi risiko kasus diare pada balita terhadap desa stop BAB sembarangan}

Hasil peta distribusi risiko diare balita terhadap status gizi buruk balita (Gambar 5) menunjukkan sebagian besar wilayah kecamatan di kabupaten banyumas memiliki risiko rendah (13 kecamatan), 
diikuti risiko sedang (7 kecamatan) dan risiko tinggi (7 kecamatan). Kecamatan yang berisiko tinggi antara lain Ajibarang, Cilongok, Sumbang, Kembaran, Sokaraja, Kemranjen dan Kebasen.

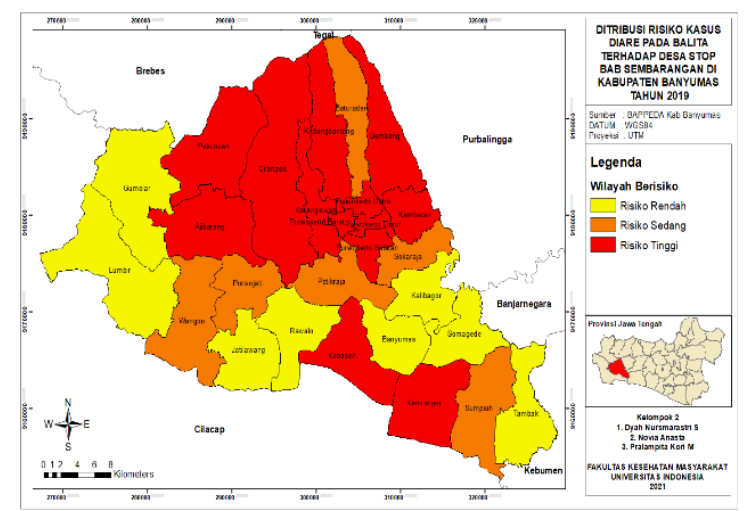

Gambar 5. Distribusi Kasus Diare pada Balita Terhadap Desa Stop BAB Sembarangan di Kab. Banyumas Tahun 2019

\section{Wilayah Rentan Diare pada Balita}

Berdasarkan parameter yang mempengaruhi kejadian diare pada balita (kepadatan penduduk, sarana air minum memenuhi syarat, cakupan KK akses jamban sehat, desa stop BABS dan status gizi buruk balita) yang telah di analisis spasial menggunakan metode skoring dan penjumlahan skoring lalu dikategorikan menjadi 3 tingkat kerentanan, menghasilkan peta wilayah kerentanan diare pada balita per kecamatan.

Peta kerentanan diare (Gambar 6) menunjukkan sebagian besar kecamatan di Kabupaten Banyumas memiliki tingkat kerentanan diare pada balita kategori sedang (11 kecamatan), diikuti tingkat kerentanan tinggi (10 kecamatan) dan tingkat kerentanan rendah (6 kecamatan). Kecamatan yang memiliki kerentanan tinggi antara lain Pekuncen, Ajibarang, Kedungbanteng, Karanglewas, Patikraja, Purwokerto Barat, Purwokerto Timur, Sumbang, Kembaran dan Kemranjen.

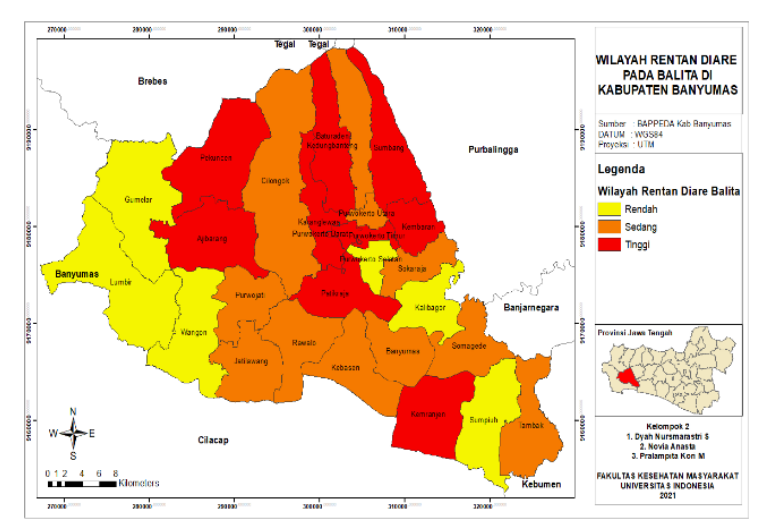

Gambar 6. Peta Kerentanan Diare pada Balita di Kab. Banyumas Tahun 2019

\section{Buffer jangkauan pelayanan puskesmas}

Hasil analisis spasial buffer terhadap jangkauan pelayanan puskesmas menunjukkan apabila menggunakan buffer sejauh $3 \mathrm{~km}$ masih banyak wilayah kerja yang belum tercover pelayanan puskesmas. Di buffer sejauh $5 \mathrm{~km}$ sudah mulai terlihat wilayah kerja beberapa puskesmas tercover pelayanan, namun baru di buffer $9 \mathrm{~km}$ menunjukkan hampir seluruh wilayah sudah tercover pelayanan puskesmas. Namun untuk daerah di sebelah utara tidak termasuk ke dalam cakupan pelayanan puskesmas dengan radius $>9 \mathrm{~km}$ dikarenakan sudah masuk daerah puncak Gunung Slamet sehingga tidak terdapat pemukiman penduduk. 


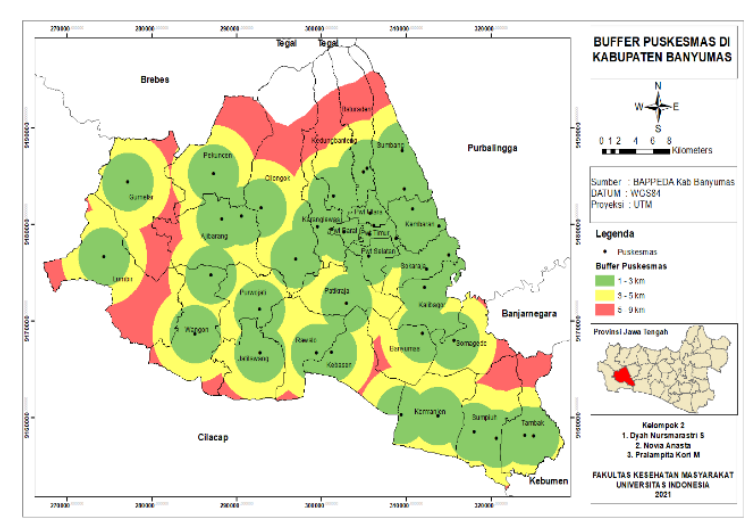

Gambar 7. Buffer jangkauan pelayanan puskesmas di Kabupaten Banyumas

\section{PEMBAHASAN}

Distribusi risiko kasus diare pada balita terhadap kepadatan penduduk

Kepadatan penduduk menjadi salah satu faktor risiko kejadian diare pada balita. Kasus diare cenderung terjadi di daerah dengan populasi tinggi dan lingkungan perumahan yang padat sehingga mempengaruhi kondisi sumber air, pembuangan tinja dan tempat pembuangan sampah (9).

Setelah dilakukan analisis korelasi didapatkan peta distribusi risiko kasus diare pada balita terhadap kepadatan penduduk yang menunjukkan bahwa semakin padat penduduk semakin tinggi pula risiko terjadi kasus diare pada balita.

Hal ini sesuai dengan Santoso (2013) dimana kepadatan penduduk sangat berpengaruh terhadap penyebaran penyakit diare, dikarenakan lingkungan akan menjadi sangat kumuh, sanitasi kurang baik, dan pengelolaan sampah kurang yang buruk (12).

\section{Distribusi risiko kasus diare pada balita} terhadap sarana air minum memenuhi syarat

Sarana air minum merupakan faktor risiko yang erat hubungannya dengan diare balita mengingat diare merupakan waterborne disease. Setelah dilakukan analisis korelasi didapatkan peta distribusi risiko kasus diare pada balita terhadap sarana air minum yang memenuhi syarat. Peta tersebut menunjukkan bahwa semakin sedikit sarana air minum yang memenuhi syarat semakin tinggi pula risiko penularannya.

Hal ini sesuai dengan Wandansari (2013), yang menyatakan bahwa sarana air minum akan mempengaruhi penularan diare dikarenakan. Dari hasil analisis korelasi didapatkan bahwa tersedianya sarana air minum yang tidak memenuhi syarat meningkatkan risiko terjadinya diare pada balita dalam suatu wilayah. Hal ini dikarenakan tubuh membutuhkan air minum dan air menyusun $90 \%$ tubuh manusia. Air memiliki berbagai fungsi utama salah satunya sebagai media transportasi dalam tubuh. Ketika sumber air minum tidak sesuai syarat baik secara fisik, kimia dan bakteriologis, air dapat menjadi media sarang dan penularan penyakit yang berbahaya. Pada kasus diare sarana air minum yang dikonsumsi belum memenuhi syarat pada aspek bakteriologis (13). 
Distribusi risiko kasus diare pada balita terhadap status gizi buruk

Gizi buruk merupakan faktor risiko yang mempengaruhi kejadian diare balita. Setelah dilakukan analisis korelasi didapatkan peta distribusi risiko kasus diare pada balita terhadap status gizi buruk yang menunjukkan bahwa semakin jelek status gizi buruk semakin tinggi pula risiko terjadinya diare pada balita.

Hal ini sesuai dengan Andry dan Palupi (2009), yang menyatakan bahwa status gizi buruk akan mempengaruhi penularan diare dikarenakan gizi berhubungan erat dengan makanan dan proses pencernaan dimulai dari digesti, absorpsi, transportasi, penyimpanan, metabolisme, dan pengeluaran zat-zat yang tidak digunakan. Diare dapat menyebabkan terjadinya malnutrisi dan berlaku sebaliknya. Status gizi kurang juga akan mengganggu pembentukan kekebalan, mengganggu fungsi sel granulosit, dan mengurangi kadar komplemen sehingga memudahkan terjadinya kesakitan diare pada balita (14).

\section{Distribusi risiko kasus diare pada balita terhadap cakupan KK akses jamban sehat}

Cakupan KK terhadap akses jamban sehat merupakan faktor risiko yang erat hubungannya dengan diare balita. Rumah tangga yang mempunyai kebiasaan membuang tinja yang tidak sesuai aturan akan meningkatkan risiko diare pada balita sebesar 2 kali lipat dibandingkan dengan rumah tangga yang mempunyai kebiasaan membuang tinja sesuai aturan (15).

Setelah dilakukan analisis korelasi didapatkan peta distribusi risiko kasus diare pada balita terhadap cakupan KK pada akses jamban sehat. Peta tersebut menunjukkan bahwa semakin tinggi persentase cakupan KK terhadap jamban sehat, maka akan semakin rendah tingkat risiko terjadinya diare. Hal ini sesuai dengan hasil penelitian Rohmah (2016) yang menyatakan bahwa rumah tangga yang menggunakan WC yang memenuhi syarat dan sehat untuk buang air kecil dan besar mempunyai risiko lebih kecil bagi anggota keluarga untuk tertular penyakit (15).

\section{Distribusi risiko kasus diare pada balita terhadap desa stop BAB sembarangan}

Buang air besar sembarangan menjadi salah satu faktor risiko kejadian diare pada balita. Kebiasaan buang air besar sembarangan tersebut juga menjadi salah faktor yang mendorong warga masyarakat untuk bersikap malas untuk menggunakan jamban umum (16). BAB sembarangan tetap menjadi penyebab utama pencemaran air, penyebaran penyakit menular yang segera membawa dampak kesehatan masyarakat (17). 
Pilar pertama dari Lima Pilar STBM adalah Stop Buang Air Besar Sembarangan, dimana Stop Buang Air Besar Sembarangan merupakan wujud pemberdayaan masyarakat desa dengan kemandirian mampu merubah perilaku hidup bersih dan sehat dari masyarakat yang buang air besar disembarang tempat menjadi buang air besar di jamban yang sehat. Kebiasaan BABS ini terjadi karena tidak adanya pengamanan tinja yang memenuhi syaratsyarat kesehatan, sehingga menimbulkan dampak yang merugikan bagi kesehatan baik untuk individu yang melakukan praktik BABS maupun komunitas lingkungan tempat hidupnya (18).

Setelah dilakukan analisis korelasi didapatkan peta distribusi risiko kasus diare pada balita terhadap desa stop buang air besar sembarangan (BABS) yang menunjukkan bahwa, semakin banyak desa yang menerapkan stop buang air besar sembarangan (BABS), maka semakin rendah risiko penularan diare di desa tersebut.

\section{Wilayah Rentan Diare pada Balita}

Berdasarkan hasil analisis spasial untuk kategori kerentanan tinggi kejadian diare pada balita berada di 10 kecamatan yaitu kecamatan Pekuncen, Ajibarang, Kedungbanteng, Karanglewas, Patikraja, Purwokerto Barat, Purwokerto Timur, Sumbang, Kembaran dan Kemranjen. Dari
10 kecamatan tersebut diidentifikasi dari hasil klasifikasi 5 parameter, sebagian besar memang memiliki risiko tinggi dan sedang.

Pada parameter kepadatan penduduk, kecamatan Purwokerto Timur dan Purwokerto Barat memiliki tingkat kepadatan penduduk yang tinggi. Parameter cakupan KK akses jamban sehat, dimana dari 10 kecamatan kerentanan tinggi kejadian diare balita, hanya kecamatan Purwokerto Barat yang berisiko sedang selebihnya berisiko tinggi. Pada parameter sumber air minum yang memenuhi syarat, 4 kecamatan memiliki risiko tinggi karena rendahnya sumber air minum yang memenuhi syarat yaitu kecamatan Pekuncen, Patikraja, Purwokerto Barat, dan Kemranjen. Parameter status gizi buruk 4 kecamatan teridentifikasi berisiko tinggi yaitu kecamatan Ajibarang, Sumbang, Kembaran dan Kemranjen. Parameter desa stop BAB sembarangan diidentifikasi 5 kecamatan masih berisiko tinggi yaitu kecamatan Kedungbanteng, Karanglewas, Purwokerto Barat, Purwokerto Timur dan Sumbang.

Jika dikaitkan angka kasus diare pada balita dengan wilayah kerentanan tinggi diare pada balita, diidentifikasi kecamatan Sumbang memiliki kasus tertinggi diare pada balita. Kecamatan Sumbang memiliki tingkat risiko tinggi dimana parameter cakupan KK akses jamban sehat yang masih rendah, status gizi buruk yang tinggi dan 
masih sedikitnya desa di kecamatan Sumbang yang baru menerapkan stop BAB sembarangan.

Diare pada balita memang erat kaitannya dengan kesehatan lingkungan, dari 5 parameter yang digunakan, didapatkan gambaran untuk wilayah yang memiliki kerentanan tinggi terhadap kejadian diare pada balita. Perlunya komitmen dan upaya pencegahan berbagai pihak tentunya sangat diperlukan mengingat wilayah dengan kerentanan tinggi kasus diare pada balita di Kabupaten Banyumas cukup banyak, sehingga harus dilakukan upaya pencegahan khususnya pada sektor lingkungan.

\section{Buffer jangkauan ke pelayanan puskesmas}

Puskesmas dalam melaksanakan tugasnya sebagai unit pelaksana teknis, memiliki suatu wilayah kerja yang menjadi tanggung jawabnya untuk meningkatkan status kesehatan pada masyarakatnya. Berdasarkan standar radius pencapaian ke puskesmas yang ideal menurut Badan Standardisasi Nasional (2004) adalah sejauh $3 \mathrm{~km}$ (19). Hal ini berkaitan dengan persepsi keterjangkauan masyarakat terhadap fasilitas pelayanan kesehatan (10).

Berdasarkan hasil buffer jangkauan pelayanan puskesmas, didapatkan bahwa masih banyak wilayah yang belum tercover jangkauan pelayanan puskesmas yang ideal yaitu jarak $3 \mathrm{~km}$. Bahkan dalam buffer $5 \mathrm{~km}$ masih banyak wilayah yang belum tercover jangkauan pelayanan puskesmas Hal ini perlu menjadi perhatian lebih bagi pihak puskesmas yang wilayah kerjanya belum tercover jangkauan pelayanan. Jarak maksimal fasilitas pelayanan kesehatan yaitu sejauh $5 \mathrm{~km}$, dimana jangkauan pelayanannya maksimal $3 \mathrm{~km}$ (11).

Jangkauan pelayanan kesehatan sangat berpengaruh terhadap status kesehatan masyarakat di sekitar pelayanan kesehatan. Daerah yang fasilitas pelayanan kesehatannya lebih dekat dan mudah untuk dicapai, kesehatan masyarakatnya akan lebih terjamin daripada daerah yang jauh dari fasilitas kesehatan, serta penemuan kasus penyakit akan lebih cepat terdeteksi (8).

Hasil buffer pelayanan puskesmas juga menggambarkan dari peta wilayah kerentanan tinggi kasus diare pada balita di Kabupaten Banyumas, merupakan wilayah yang masih dalam jarak pelayanan kesehatan maksimal ke masyarakat yaitu 5 $\mathrm{km}$.

Hal ini perlu menjadi evaluasi khususnya kesehatan lingkungan masyarakat oleh pihak puskesmas pada daerah rentan, dimana dilihat dari faktor risiko lingkungan yang digunakan dalam penelitian menunjukkan wilayah rentan yang teridentifikasi termasuk berisiko tinggi. 
Terima kasih kepada Dinas Kesehatan Kabupaten Banyumas dan Badan Pusat Statistik Kabupaten Banyumas atas penyediaan sumber data sehingga penelitian ini dapat dilaksanakan.

\section{KESIMPULAN}

Berdasarkan analisis spasial yang telah dilakukan, didapatkan peta persebaran diare yang menunjukkan bahwa kasus cenderung akan meningkat pada wilayah dengan karakteristik kepadatan penduduk tinggi, minimnya sarana air minum memenuhi syarat, tingginya jumlah balita dengan status gizi buruk, rendahnya cakupan KK terhadap akses jamban sehat dan rendahnya angka stop $\mathrm{BAB}$ sembarangan. Hasil pemetaan kerentanan diare pada balita di Kabupaten Banyumas, didapatkan 10 Kecamatan yang memiliki kerentanan tinggi terhadap kejadian diare pada balita yaitu kecamatan Pekuncen, Ajibarang, Kedungbanteng, Karanglewas, Patikraja, Purwokerto Barat, Purwokerto Timur, Sumbang, Kembaran dan Kemranjen. Hasil analisis buffer menunjukkan masih banyak kecamatan di Kabupaten Banyumas yang belum termasuk pada jangkauan pelayanan puskesmas yang ideal. Sehingga beberapa kecamatan tersebut lebih rentan terhadap risiko diare dikarenakan jangkauan puskesmas sangat berpengaruh terhadap status kesehatan masyarakat.

Saran yang dapat diberikan kepada dinas kesehatan dan puskesmas yaitu dapat memberikan perhatian lebih terhadap kesehatan lingkungan dan status kesehatan balita pada 10 kecamatan yang memiliki kerentanan tinggi agar dapat mencegah terjadinya peningkatan kasus atau KLB diare pada balita. Puskesmas di Kabupaten Banyumas dapat lebih meningkatkan kewaspadaan peningkatan kasus diare balita pada daerah wilayah kerja yang jauh dari jangkauan pelayanan puskesmas. Selain itu, perlu dilakukan penelitian lanjutan mengenai "pengembangan sistem informasi geografis penyakit diare balita di Kabupaten Banyumas" untuk mendapatkan gambaran kekuatan hubungan faktor risiko terhadap kejadian diare balita.

\section{DAFTAR PUSTAKA}

1. United Nations Children's Fund (UNICEF). One is Too Many: Ending child deaths from pneumonia and diarrhoea. New York: UNICEF; 2016.

2. Pusat Data dan Informasi Kementrian Kesehatan RI. Buletin Jendela Data \& Informasi Kesehatan: Situasi Diare di Indonesia. Jakarta: Pusat Data dan Informasi Kementrian Kesehatan RI; 2011. 
3. Kementrian Kesehatan RI. Profil Kesehatan Indonesia Tahun 2019. Jakarta; 2020.

4. Dinas Kesehatan Kabupaten Banyumas. Profil Kesehatan Kabupaten Banyumas, 2019 [Internet]. Badan Pusat Statistik. 2019 [cited 2020 Dec 25]. Available from: https://sirusa.bps.go.id/sirusa/index.p $\mathrm{hp} /$ sektoral/view?kd=12766\&th=201 9

5. Utami N, Luthfiana N. Faktor-Faktor yang Memengaruhi Kejadian Diare pada Anak. J Major. 2016;5(4):101-6.

6. Chandra B. Pengantar Kesehatan Lingkungan. Jakarta: EGC; 2013.

7. Prasetyo LB. Pembobotan (Weighting). In: Spatial Database Analysis Facilities (SDAF). Bogor: Departemen Konservasi Sumberdaya Hutan Dan Ekowisata Fakultas Kehutanan Institut Pertanian Bogor; 2011.

8. Prastiwi AK. Penyajian Data Spasial Distribusi Kasus Tuberkulosis di Puskesmas Gedongtengen Yogyakarta. [Yogyakarta]: Universitas Gadjah Mada; 2014.

9. Ureani DW. Analisis Spasiotemporal Kasus Diare Pada Balita di Kecamatan Tembalang Periode Oktober 2009 - Februari 2010. [Semarang]: Universitas Diponegoro; 2010 .
10. Adawiyah R, Sutomo AH. Analisis Spasial Pemanfaatan Sumber Air Minum, Sanitasi Dasar dan Aksesibilitas Fisik Kejadian Diare Pada Balita di Kecamatan Gandus Kota Palembang. [Yogyakarta]: Universitas Gadjah Mada; 2012.

11. Setiawan A, Lazuardi L, Hakimi M. Analisis Distribusi Spasial Kematian Ibu di Kabupaten Banjarnegara Tahun 2011 - 2013. J Inf Syst Public Heal. 2017;1(3):52-60.

12. Dimaz SP. Analisis Distribusi Penyakit Diare dan Faktor Resiko Tahun 2011 Dengan Pemetaan Wilayah Puskesmas Kagok Semarang. [Semarang]: Universitas Dian Nuswantoro; 2013.

13. Wandansari AP. Kualitas Sumber Air Minum dan Pemanfaatan Jamban Keluarga dengan Kejadian Diare. KEMAS J Kesehat Masy. 2013;9(1):24-9.

14. Gibney MJ. Gizi kesehatan masyarakat/Public Health Nutrition. Hartono A, Hardiyanti EA, Widyastuti P, editors. Jakarta: EGC; 2009.

15. Rohmah N. Hubungan Antara PHBS, Penggunaan Air Bersih dan Jamban Sehat di Rumah Tangga dengan Kejadian Diare Pada Balita di Wilayah Kerja Puskesmas Sekardangan Kabupaten Sidoarjo. 
[Surabaya]: Universitas Airlangga; 2016.

16. Dewi C, Naraha JA. Analisis Faktor Lingkungan Terhadap Perilaku Buang air Besar Sembarangan Masyarakat Desa Lermatang Kabupaten Maluku Tenggara Barat. Infokes Info Kesehat. 2019;9(2):139-50.

17. Saleem M, Burdett T, Heaslip V. Health and social impacts of open defecation on women: a systematic review. BMC Public Heal 2019191. 2019;19(1):1-12.

18. Dinkes Kabupaten Berau. STOP Buang Air Besar Sembarangan [Internet]. Dinkes Kabupaten Berau. 2020 [cited 2020 Dec 12]. Available from:

http://dinkes.beraukab.go.id/index.ph p/en-us/component/k2/item/336-stopbuang-air-besar-sembarangan

19. Badan Standardisasi Nasional. Standar Nasional Indonesia Tata cara perencanaan lingkungan perumahan di perkotaan Badan Standardisasi Nasional. Bandung: Badan Standardisasi Nasional; 2003. 